\title{
MODEL PEMBELAJARAN LITERASI KEUANGAN MELALUI PENDEKATAN PROBLEM BASED LEARNING
}

\author{
Oleh : Lilik Sulistyowati \\ Balai Pengembangan Pendidikan Anak Usia Dini dan Pendidikan Masyarakat Provinsi Bali \\ liliksulistyowati743@yahoo.co.id
}

\begin{abstract}
Abstrak: Pembelajaran multikeaksaraan merupakan pembelajaran yang dapat memelihara dan meningkatkan kemampuan keberaksaraan masyarakat sehingga diperlukan adanya model pembelajaran literasi keuangan dengan Pendekatan Problem Based Learning (PBL). Model ini disusun atas dasar hasil studi pendahuluan yang telah dilakukan bahwa warga belajar keaksaraan dasar yang telah memperoleh SUKMA dapat meningkatkan kemampuan literasinya dalam bidang keuangan. Masyarakat diharapkan dapat mengerti dan melakukan transaksi keuangan, tidak mudah tergiur oleh transaksi keuangan yang ilegal, dan memanfaatkan uangnya untuk kebutuhan mendatang. Penelitian ini dilakukan untuk mendeskripsikan: (1) tingkat validitas model pembelajaran literasi keuangan dengan pendekatan PBL; (2) tingkat efektivitas model pembelajaran literasi keuangan dengan pendekatan PBL; (3) hasil penerapan model pembelajaran literasi keuangan dengan pendekatan PBL. Metode pengembangan model menggunakan kuasi eksperimen. Instrumen pengumpulan data meliputi: (1) kuesioner, (2) tes, (3) wawancara, dan (4) pengamatan. Hasil analisis yang diperoleh adalah sebagai berikut: (1) model pembelajaran literasi keuangan dengan pendekatan PBL, panduan pembelajaran dan panduan penilaian, dan bahan ajar secara keseluruhan diperoleh hasil rerata uji coba sebesar 77,80 atau dalam kriteria baik atau valid; (2) hasil uji efektivitas model t hitung 17,60., t tabel dengan db 49 dan taraf kepercayaan 95\% diperoleh harga t 2,060, maka t hitung > daripada $\mathrm{t}$ tabel sehingga hipotesis nol ditolak, kesimpulannya model tersebut efektif dalam meningkatkan hasil belajar program keaksaraan; (3) hasil uji coba penerapan bahan ajar, uji coba penerapan untuk pendidik, uji coba terhadap peserta didik diperoleh rerata skor 76,32 atau dalam kriteria baik sehingga model dapat diterapkan.
\end{abstract}

Kata kunci : literasi kKeuangan, problem based learning, multikeaksaraan.

\section{FINANCIAL LITERACY LEARNING MODEL WITH PROBLEM BASED LEARNING APPROACH}

\begin{abstract}
Multi-literacy learning is learning to maintain and improve people's literacy skills. Financial literacy learning model is needed with the Problem Based Learning (PBL) approach. This model is compiled on the basis of the results of preliminary studies have been conducted shows learning basic literacy who obtained SUKMA, improve in literacyskills offinancialsector. The public is expected to be able to understand and carry out financial transactions, not be easily tempted by illegal financial transactions, and to use the money for future needs. This paper was described: The level of validity, level of effectiveness, and result of applications of the financial literacy learning model using PBL approach. The model development method uses a quasi-experimental. The data collection instruments included: (1) questionnaires, (2) tests, (3) interviews, and (4) observations. The results of the analysis are as follows:
\end{abstract}


(1) The financial literacy learning model with the PBL approach, the Learning Guide and Assessment Guide, and overall teaching materials obtained a mean test result of 77.80 or in the Good or Valid criteria. (2) The results of the effectiveness test of the model t count 17.60. $t$ table with $d b 49$ and a confidence level of $95 \%$ obtained t price 2.060 then $t$ count $>$ than $t$ table so that the null hypothesis is rejected. The conclusion of this model is effective in improving the learning outcomes of the literacy program. (3) The results of testing the application of teaching materials, application trials for educators, trials on students obtained an average score of 76.32 or in good criteria so that the model can be applied.

Keywords: financial literacy, problem based learning, multiliteracy.

\section{PENDAHULUAN}

\section{Latar Belakang}

Di tengah kemajuan Provinsi Bali yang sudah terkenal hingga ke penjuru dunia ternyata masih terdapat penduduk penyandang buta aksara. Menurut Badan Pusat Statistik Bali (2017), jumlah masyarakat buta aksara usia 15 tahun ke atas rata-rata sebesar 7,1\% terdiri atas penduduk laki-laki 3,6\% dan perempuan 10,6\%. Meskipun ada kecenderungan menurun apabila dibandingkan dengan buta aksara tahun 2016, yakni rata-rata 7,18\% yang terdiri atas penduduk laki-laki 3,63\% dan perempuan $10,77 \%$, tetapi penurunan tersebut belum signifikan.

Apabila dibandingkan dengan kondisi kependudukan secara nasional, angka buta aksara di Provinsi Bali untuk penduduk usia 15-59 tahun sebanyak 105.307 terdiri atas penduduk laki-laki sebesar 27.879 dan penduduk perempuan 77.428 atau persentase 2,04\% laki dan $7,71 \%$ perempuan dengan rata-rata $3,87 \%$ menempati urutan ketujuh dari 34 provinsi di Indonesia. Dari keseluruhan kabupaten/kota yang ada di Bali, Kabupaten Karangasem menjadi salah satu kabupaten yang jumlah angka buta aksaranya masuk urutan 7 terbesar di Indonesia.
Tingginya angka buta aksara di Provinsi Bali disebabkan oleh beberapa faktor, antara lain: sebagian besar penyandang buta aksara sudah masuk usia di atas 59 tahun sehingga sulit sekali untuk mengikuti proses pembelajaran. Di samping itu, minat untuk mengikuti proses pembelajaran sangat rendah,sehingga keberlangsungan program keaksaraan tidak bisa terjamin.

Pemerintah melalui Dinas Pendidikan telah meluncurkan berbagai jenis program keaksaraan untuk masyarakat, seperti program keaksaraan dasar, keaksaraan fungsional, dan Taman Bacaan Masyarakat. Upaya yang dilakukan oleh pemerintah tersebut tampaknya belum banyak berhasil untuk menghapuskan angka buta aksara di Provinsi Bali.

Faktor lain yang turut menjadi penyebab belum berhasilnya program pendidikan keaksaraan dalam menurunkan angka buta aksara adalah pembelajaran keaksaraan masih dilaksanakan secara konvensional,sehingga dianggap belum bermakna bagi warga belajar. Ditambah lagi, belum ada keberlangsungan program keaksaraan secara konsisten sehingga masyarakat yang telah menamatkan program keaksaraan dasar dengan kemampuan yang masih terbatas menjadi lupa dan kembali menjadi penyandang buta aksara. 
Hal di atas tidak bisa dibiarkan terusmenerus. Program pendidikan keaksaraan tingkat dasar harus diupayakan untuk berkelanjutan, antara lain melalui program pendidikan multikeaksaraan yang memberikan kesempatan kepada warga belajar untuk terus dapat meningkatkan kemampuan literasinya, baik pada kemampuan membaca, menulis, maupun berhitung.

Program pendidikan multikeaksaraan bertujuan agar warga belajar dapat memperoleh pengetahuan, sikap, dan keterampilan dalam bidang lain, seperti: (1) profesi, keahlian, dan pekerjaan, seperti pekerjaan dan usaha di bidang pertanian, (2) pengembangan seni budaya, seperti kearifan budaya lokal, (3) sosial, politik dan kebangsaan, , (4) kesehatan dan olahraga, seperti kesehatan lansia, (5) ilmu pengetahuan dan teknologi, seperti literasi keuangan.

Perluasan peningkatan pengetahuan, keterampilan, dan sikap tersebut sangat sesuai dengan kebutuhan masyarakat sehingga proses pembelajaran akan lebih menarik minat warga belajar karena sesuai dengan kebutuhan nyata mereka dalam kehidupan sehari-hari. Dengan terlaksananya proses pembelajaran, kemampuan literasinya bisa meningkat dan terpelihara sehingga mereka tidak mengalami buta aksara kembali.

Sehubungan dengan pentingnya pendidikan multikeaksaraan untuk meningkatkan pengetahuan, keteram-pilan, dan sikap warga belajar, khususnya dalam memelihara dan meningkatkan kemampuan literasinya, BP PAUD dan Dikmas Provinsi Bali mengembangkan model Pembelajaran Literasi Keuangan dengan Pendekatan Problem Based Learning (PBL).

Model ini disusun atas dasar hasil studi pendahuluan yang telah dilakukan bahwa warga belajar keaksaraan dasar yang telah memperoleh SUKMA berkeinginan untuk meningkatkan kemampuan literasinya, khususnya dalam bidang keuangan dengan mengusahakan keterampilan tertentu untuk diupayakan sebagai bekal mencari penghasilan. Usaha yang akan ditekuni adalah jenis usaha anyaman bambu, pembuatan ingka, dan kue. Untuk mendukung usaha tersebut, diperlukan pula kemampuan literasi keuangan, yang berhubungan dengan perencanaan keuangan, catatan-catatan pembelian, penjualan, dan menghitung untung dan rugi, bahkan melakukan transaksi keuangan dengan Perbankan.

Model pembelajaran PBL dipilih dalam pembelajaran karena pada dasarnya orang dewasa akan mau belajar apabila apa yang dipelajari itu berhubungan dengan masalah yang dihadapi sehingga apa yang dipelajari bermakna bagi dirinya. Model pembelajaran PBL mengutamakan pembelajaran berdasarkan masalah.

Berangkat dari masalah tersebut, secara individual atau berkelompok warga belajar berupaya mencari solusi untuk memecahkannya, sehingga hasilnya dapat memberikan manfaat bagi warga belajar.

Literasi keuangan merupakan pengetahuan, sikap, dan keterampilan bidang keuangan yang sangat dibutuhkan oleh warga masyarakat. Keterbatasan dalam literasi keuangan mengakibatkan banyaknya warga masyarakat yang tidak efektif dalam pengelolaan keuangan. Banyak masyarakat menjadi korban imingiming investasi bodong yang menawarkan harapan keuntungan yang tinggi, pinjaman online ilegal dengan bunga yang mencekik, tabungan dengan iming-iming bunga tinggi dan berhadiah, serta bentuk-bentuk penipuan lainnya. Penguasaan literasi keuangan yang baik akan meningkatkan kesadaran warga belajar dalam pengelolaan keuangan yang tepat. Oleh 
karena itu, pembelajaran keaksaraan dengan tema literasi keuangan menjadi sesuatu yang menarik bagi warga belajar karena literasi keuangan merupakan masalah nyata yang dihadapi oleh warga belajar dalam kehidupan sehari-hari.

\section{Rumusan Masalah}

Berdasarkan latar belakang di atas, rumusan masalah pengembangan model ini adalah:

a. Bagaimana validitas model pembelajaran literasi keuangan dengan pendekatan Problem Based Learning?

b. Bagaimanakah efektivitas hasil penerapan model pembelajaran literasi keuangan dengan pendekatan Problem Based Learning?

\section{Tujuan Pengembangan}

Berdasarkan rumusan masalah di atas, tujuan pengembangan adalah sebagai berikut.

a. Mendeskripsikan validitas model pembelajaran literasi keuangan dengan pendekatan Problem Based Learning.

b. Mendeskripsikan efektivitas model pembelajaran literasi keuangan dengan pendekatan Problem Based Learning.

\section{PEMBELAJARAN PROBLEM BASED LEARNING}

\section{Pembelajaran PBL}

Problem Based Learning (PBL) adalah pengajaran dengan pendekatan yang efektif untuk proses berpikir tingkat tinggi. Pembelajaran ini membantu peserta didik untuk memproses informasi dan menyusun pengetahuan mereka mengenai dunia sosial dan sekitarnya.

Menurut Duch (1995) dalam Aris Shoimin (2014), Problem Based Learning (PBL) atau pembelajaran berbasis masalah adalah model pengajaran yang bercirikan adanya permasalahan nyata sebagai konteks untuk para peserta didik belajar berpikir kritis dan keterampilan memecahkan masalah serta memperoleh pengetahuan. PBL mempersiapkan peserta didik untuk berpikir kritis, analitis, dan mencari serta menggunakan sumber pembelajaran yang tepat.

Hal senada dikemukakan oleh Taufiq Amir (2009), bahwa PBL tidak hanya sekadar prosedur, tetapi belajar mengelola diri sebagai kecakapan hidup. Pembelajaran PBL memang ada prosedur yang harus diikuti, dari perumusan masalah sampai penilaian. Prosedur ini disusun dengan maksud agar pelaksanaan pembelajaran berlangsung secara sistematis dan berjalan lancar. Penerapan PBL bermakna lebih dari hanya sekadar prosedur, tetapi warga belajar belajar mengelola diri sebagai kecakapan hidup. Kecakapan hidup dimaksud adalah kecakapan dalam menentukan masalah, memecahkan masalah berdasarkan rujukan yang factual, dan menetapkan solusi berdasarkan pemikiran dan data dukung yang kuat.

PBL melatih warga belajar untuk menyusun pengetahuannya sendiri dan mengembangkan keterampilan dalam memecahkan masalah. Dengan pemberian masalah nyata, peserta didik dapat menyusun makna dari bahan pelajaran melalui proses belajar dan menyimpan dalam memori sehingga dapat digunakan lagi di kemudian hari.

Pendekatan PBL dipilih sebagai model dalam pendekatan pembelajaran orang dewasa karena pembelajaran orang dewasa akan berhasil dengan baik apabila apa yang dipelajari dapat membantu memecahkan permasalahan yang dihadapi dalam kehidupannya. Oleh karena itu, bagi orang dewasa, belajar dimulai dari masalah yang dihadapinya dan berusaha untuk memperoleh pemecahan terhadap masalah yang dihadapinya.

Peran tutor dalam pembelajaran berbasis masalah adalah mengindentifikasi masalah 
bersama peserta didik, menyajikan masalah, mengajukan masalah, dan memfasilitasi penyelidikan dan diskusi untuk memecahkan masalah, serta memberikan penghargaan terhadap hasil karya peserta didik. Dengan pendekatan tersebut, diharapkan peserta didik akan bergairah belajar karena peserta didik merasakan manfaatnya atas proses pembelajaran yang dipelajarinya.

\section{Ciri-Ciri Pendekatan PBL}

Model pendekatan problem based learning memiliki karakteristik yang berbeda dengan model pendekatan pembelajaran yang lain. Karakteristik pendekatan model PBL untuk tiap-tiap komponen sebagaimana yang dikutip oleh Richard I. Arends (2008) tersebut adalah sebagai berikut: (1) pembelajaran berdasarkan masalah, artinya apa yang dipelajari disesuaikan dengan masalah warga belajar; (2) berfokus pada keterkaitan antardisiplin, artinya berhubungan dengan berbagai disiplin ilmu yang lain, (3) penyelidikan autentik, yakni melaksanakan pembelajaran sesuai dengan kondisi nyata kehidupan sehari-hari, (4) menghasilkan produk dan memamerkannya, artinya warga belajar dapat merasakan dan mempertunjukkan hasil yang dipelajari, dan (5) kolaborasi dan kerja sama, yaitu memerlukan kerja sama yang kompak antarwarga belajar dalam mencapai tujuan bersama.

\section{Langkah-Langkah PBL}

Pendekatan Problem Based Learning dilaksanakan dengan proses tujuh langkah. Langkah-langkah tersebut adalah sebagai berikut.

(1) Identifikasi permasalahan, artinya masalah yang diangkat berdasarkan kebutuhan belajar warga belajar; (2) Orientasi peserta didik terhadap suatu masalah, yaitu menjelaskan tujuan pembelajaran dan aktivitas apa yang akan dilakukan; (3) Mengorganisasikan peserta didik, yaitu membantu peserta didik mengelompokkan tugas belajar yang berhubungan dengan masalah yang telah ditetapkan, membentuk kelompok kecil, kemudian mencoba untuk memecahkan masalah yang ditemukan tersebut; (4) Membimbing individu dan kelompok untuk mengumpulkan informasi sebanyakbanyaknya, mencoba memecahkan masalahnya, menemukan ide-ide, dan pemecahan masalah; (5) Mengembangkan dan menyajikan hasil karya peserta didik memberi argumen terhadap jawaban pemecahan masalah, serta mempertunjukkan hasil karya peserta didik; dan (6) Menganalisis dan mengevaluasi proses penyelesaian masalah, yaitu tutor dan peserta didik menganalisis dan mengevaluasi penyelesaian masalah yang dipresentasikan oleh masing-masing kelompok.

\section{Kelebihan Pendekatan PBL}

Kelebihan pembelajaran PBL dibandingkan dengan model pembelajaran yang lainnya adalah sebagai berikut.

(1) Pemecahan masalah merupakan teknik yang baik dan menjadi daya tarik warga belajar untuk memahami isi pelajaran; (2) Pemecahan masalah dapat mendorong kemampuan peserta didik dan memberikan kepuasan dalam menemukan pengetahuan baru untuk peserta didik; (3) Pemecahan masalah meningkatkan aktivitas dan kreativitas peserta didik sehingga belajar menjadi menyenangkan; (4) Pemecahan masalah dapat membantu peserta didik dalam menguasai pengetahuan serta untuk memahami masalah dalam kehidupan yang sebenarnya; (5) Pemecahan masalah dapat membantu peserta didik untuk mengembangkan pengetahuan dan bertanggung jawab dalam pembelajaran yang dilakukan; (6) Melalui pemecahan warga belajar dapat terus berlatih berpikir untuk mengatasi persoalan hidup; (7) Pemecahan masalah dirasakan lebih menyenangkan dan disukai oleh peserta didik; (8) Pemecahan masalah mengembangkan kemampuan 
peserta didik untuk berpikir kritis dan mengembangkan kemampuan beradaptasi dengan pengetahuan baru; (9) Pemecahan masalah memberikan kesempatan pada peserta didik untuk menerapkan pengetahuan yang dimiliki; dan (10) Pemecahan masalah menumbuhkan minat peserta didik untuk terus- menerus belajar meskipun proses belajar pada pendidikan formal telah usai.

\section{PROGRAM PENDIDIKAN MULTIKEAKSARAAN}

Pendidikan Keaksaraan Lanjutan merupakan program pendidikan yang menyelenggarakan pembelajaran bagi peserta didik yang telah menyelesaikan program pendidikan keaksaraan dasar dalam rangka mengembangkan kompetensinya. Pendidikan Keaksaraan Lanjutan terdiri atas: (1) Pendidikan Keaksaraan Usaha Mandiri (KUM), dan (2) Pendidikan Multikeaksaraan.

Pendidikan Keaksaraan Usaha Mandiri adalah program keaksaraan dengan memberdayakan warga belajar melalui kewirausahaan. Program Pendidikan Multikeaksaraan merupakan program pembelajaran keaksaraan yang menekankan peningkatan keberagaman keberaksaraan warga masyarakat dalam berbagai aspek kehidupan sebagai upaya pemberdayaan masyarakat untuk meningkatkan keterampilan profesi, pekerjaan, atau kemahiran yang dimiliki dan diminati peserta didik.

Pendidikan multikeaksaraan disesuaikan dengan minat peserta didik mengenai wawasan keilmuan dan teknologi, kesehatan dan olahraga, seni, budaya, atau politik dan kebangsaan, serta pekerjaan atau profesi.

Pelaksanaan Pendidikan Multikeaksaraan menerapkan Kurikulum/Standar Kompetensi Lulusan (SKL) pendidikan keaksaraan lanjutan dilakukan minimal 86 jam, masing-masing lamanya 60 menit dengan mengacu pada Standar Kompetensi Lulusan Keaksaraan Lanjutan.
Peserta didik yang telah dinyatakan lulus dengan program keaksaraan lanjutan akan diberikan Surat Keterangan Melek Aksara Lanjutan (SUKMA-L) merupakan sertifikat kelulusan yang diberikan kepada peserta didik yang telah memenuhi kompetensi lulusan pendidikan keaksaraan lanjutan.

\section{Literasi Keuangan}

Menurut Kamus Besar Bahasa Indonesia, literasi adalah pengetahuan atau keterampilan dalam bidang atau aktivitas tertentu, atau kemampuan individu dalam mengolah informasi dan pengetahuan untuk kecakapan hidup. Menurut Otoritas Jasa Keuangan (2014), Literasi Keuangan atau Financial Literacy adalah tingkat pengetahuan, keterampilan, keyakinan masyarakat terkait lembaga keuangan serta produk dan jasanya yang dituangkan dalam parameter ukuran indeks. Semakin tinggi indeks literasi keuangan seseorang akan semakin meningkat kesadaran seseorang dalam memanfaatkan lembaga dan produk keuangan yang legal. Hal senada didefinisikan oleh Kemendikbud (2016), bahwa literasi keuangan adalah kombinasi dan kesadaran pengetahuan, keterampilan, dan sikap yang diperlukan untuk membuat keputusan keuangan yang sehat. Literasi keuangan meliputi kemampuan dasar bagi seseorang untuk berpartisipasi dalam aktivitas keuangan yang kompleks. Hal tersebut meliputi kemampuan menggunakan informasi yang efektif dalam mengelola uang dan produk keuangan lainnya.

Literasi keuangan memberikan pemahaman untuk mengelola keuangan dan peluang untuk mencapai kehidupan yang lebih baik di masa yang akan datang. Literasi keuangan berperan dalam membuat keputusan yang berkaitan dengan aktivitas sehari-hari, seperti dalam mengambil keputusan untuk menabung (saving) atau investasi (investment) untuk mencapai tujuan yang sudah ditentukan 
sebelumnya. Literasi keuangan selain bermanfaat bagi individunya sendiri juga bermanfaat untuk keberlangsungan sistem perekonomian suatu negara.

Literasi dan pengelolaan keuangan penting bagi setiap keluarga Indonesia karena keluarga adalah salah satu pilar perekonomian. Dengan pemahaman literasi keuangan yang merata di seluruh lapisan masyarakat, masyarakat dapat merencanakan keuangannya dengan baik, aman, dan terarah.

Edukasi literasi keuangan adalah program pemerintah yang didukung oleh perbankan nasional. Program edukasi merupakan solusi perbankan dan literasi keuangan yang dilaksanakan dengan berbagai kegiatan termasuk di antaranya dijadikan sebagai tema dalam program pembelajaran multikeaksaraan.

Sebagaimana diketahui bahwa dalam kehidupan sehari-hari, manusia tidak bisa terlepas dari penggunaan uang. Manusia bekerja untuk mendapatkan uang dan uang tersebut akan digunakan untuk memenuhi kebutuhan hidupnya. Saat ini uang tidak sebatas yang tampak secara fisik, tetapi sangat beragam bentuk uang yang digunakan. Untuk itu pengetahuan mengenai keuangan sangat penting bagi masyarakat termasuk bagaimana menyimpan, mengambil, menggunakan, dan meminjam uang dari lembaga keuangan. Pemahaman keuangan yang baik oleh masyarakat akan dapat mencegah maraknya rentenir, ijon, pembohongan dengan investasi bodong, dan sebagaimya. Oleh karena itu, dalam program multikeaksaraan dengan tema keuangan, secara rinci akan dibahas: (1) Uang dan Transaksi, (2) Perencanaan dan Pengelolaan, (3) Resiko dan Hasil, dan (4) Kejahatan Keuangan dan Pajak.

\section{Penerapan Pembelajaran Multi-keaksaraan dengan Literasi Keuangan}

Pembelajaran program multi-keaksaraan dapat dilakukan dengan berbagai pola dan strategi.
Adapun pola dan strategi pelaksanaannya adalah sebagai berikut.

a. Pembelajaran dilaksanakan sekurangkurangnya 86 jam @ 60 menit.

b. Pembelajaran dikemas dengan judul-judul yang sesuai dengan minat dan kebutuhan warga belajar.

1) Uang dan Transaksi

Kegiatan belajar ini bertujuan untuk menumbuhkan pemahaman warga belajar tentang kegunaan uang dan transaksi yang menggunakan uang.

Indikator ketercapaian proses belajarnya adalah sebagai berikut.

a) Warga belajar mampu menuliskan dan menyebutkan kembali manfaat uang sebagai alat pertukaran.

b) Warga belajar mampu menuliskan dan menyebut-kan transaksi keuangan melalui bank, membayar pajak, listrik, dan sebagainya.

c) Warga belajar dapat menuliskan, membaca, dan berhitung terkait dengan pembelian, penjualan, dan keuntungan hasil penjualan.

d) Warga belajar dapat menulis, membaca, dan memanfaatkan pencatatan keuangan dan perjanjian, seperti membuat kuitansi, panjar, dan perjanjian sewa menyewa.

2) Perencanaan dan pengelolaan kegiatan belajar ini bertujuan untuk menumbuhkan pemahaman warga belajar tentang pentingnya perencanaan dan pengelolaan keuangan.

Indikator ketercapaian proses belajarnya adalah sebagaimana berikut ini.

a) Warga belajar memiliki kesadaran untuk membuat anggaran pengeluaran dan pemasukan, seperti: menyusun pengeluaran rutin rumah tangga, menabung 
dalam bentuk bank, emas, investasi yang legal, dan merencanakan membayar zakat.

b) Warga belajar dapat melakukan transaksi kredit, seperti cara meminjam uang di bank, melengkapi persyaratannya, menghitung besarnya angsuran, merencanakan pembiayaan sewa beli rumah, dan kredit kendaraan.

\section{3) Risiko dan Hasil}

Kegiatan belajar ini bertujuan untuk menumbuhkan pemahaman warga belajar tentang kemungkinan risiko yang dialami dan hasil yang didapat dari transaksi keuangan.

Indikator ketercapaian proses belajarnya adalah sebagai berikut.

a) Warga menyadari adanya perubahan nilai pinjaman dan nilai pengembalian pinjaman.

b) Warga belajar menyadari terdapat perubahan nilai antara harga ijon dengan harga pasar, harga tunai dengan harga kredit.

c) Warga belajar dapat mengenali risiko dari meminjamkan uang kepada orang lain dan juga risiko kalau menyimpan uang tidak pada tempat yang resmi di lembaga keuangan.

d) Warga belajar menyadari pentingnya perlindungan diri dengan memiliki polis asuransi, jaminan kesehatan, tabungan bea peserta didik anaknya, dsb.

\section{Langkah-Langkah Pembelajaran}

a. Tutor mempersiapkan perangkatnya berupa RPP dan bahan ajar yang relevan dengan cakupan materi yang akan dibahas.

b. Tutor membaca dan menjelaskan materi dengan memberikan contoh-contoh yang sesuai dengan tema dan kehidupan nyata sehari-hari. c. Warga belajar mengikuti proses pembelajaran dengan aktivitas: menulis, membaca, berhitung, dan berbahasa Indonesia dengan tema sesuai yang telah disepakati bersama.

d. Tutor meminta warga belajar untuk membaca, menulis, atau menjelaskan halhal terkait dengan tema pembahasan saat itu.

e. Tutor memberikan penguatan terhadap jawaban atau hasil karya warga belajar.

f. Tutor memberikan penghargaan terhadap setiap jawaban atau hasil karya warga belajar.

\section{EVALUASI}

Evaluasi dilaksanakan pada setiap proses pembelajaran. Evaluasi dilakukan terhadap:

a. kemampuan membaca warga belajar dengan cara melihat performanya dalam membaca teks yang disediakan;

b. kemampuan menulis warga belajar dengan cara melihat hasil karya tulisan warga belajar;

c. kemampuan berhitung warga belajar dengan cara melihat hasil menghitung warga belajar terhadap persoalan yang diajukan;

d. kemampuan berbahasa Indonesia dengan cara memperhatikan komunikasi warga belajar dengan menggunakan bahasa Indonesia;

e. kemampuan keterampilan warga belajar dalam memfungsionalkan pengalaman literasinya dalam kepentingan hidup sehari-hari seperti: transaksi menabung, membayar listrik, membuat kuitansi, dan traksaksi keuangan lainnya. 


\section{METODE PENGEMBANGAN MODEL}

\section{Prosedur Pengembangan Model}

Prosedur pengembangan model sebagaimana diatur dalam Perdirjen PAUD dan Dikmas Nomor 02 Tahun 2016 meliputi empat langkah sebagai berikut.

a. Studi Eksplorasi

Studi eksplorasi dimaksudkan untuk memperoleh data/ informasi awal mengenai kondisi dan permasalahan yang dihadapi masyarakat. Hasil studi pendahuluan digunakan sebagai topik pengembangan model setelah dilaksanakan validasi judul model oleh direktorat terkait (Bindiktara).

b. Perumusan Model

Pada langkah ini, dilakukan penyusunan Draf Model (Model Konseptual) kemudian dilakukan analisis dan revisi model melalui kegiatan diskusi terpumpun dan kemudian dilakukan uji coba model konseptuan skala terbatas.

c. Uji coba, Revisi, dan Analisis

Hasil uji coba model konseptual, setelah dilakukan revisi diteruskan dengan uji coba operasional, diolah, dan dianalisis hasilnya sehingga menjadi model akhir.

d. Validasi model dan penerapan

Hasil pengembangan model akhir selanjutnya divalidasi (dibakukan) oleh direktorat terkait (Bindiktara) dan diterapkan.

\section{Rancangan Pengembangan}

Pengembangan model ini menggunakan rancangan pengembangan kuasi eksperimen Pretest-Posttest Control Group Design. Terdapat dua kelompok yang dipilih secara random, kemudian kedua kelompok diberikan pretest untuk melihat kemampuan awal, adakah perbedaan kemampuan awal antara kelompok kontrol dengan kelompok eksperimen. Hasil pretest yang baik, apabila nilai kelompok eksperimen tidak berbeda secara siginifikan dengan kelompok kontrol.
Pengaruh perlakuan adalah $(\mathrm{O} 2-\mathrm{O} 1)-(\mathrm{O} 3$ $-\mathrm{O} 4)$.

Skema dari model desain Pretest-Posttest Control Group Design adalah sebagai berikut:

$$
\begin{array}{lll}
\mathrm{O} 1 & \mathrm{X} & \mathrm{O} 2 \\
\mathrm{O} 4 & & \mathrm{O} 3
\end{array}
$$

$\mathrm{X}=$ perlakuan (model pembelajaran literasi keuangan dengan pendekatan PBL

$\mathrm{O} 1=$ tes awal kelompok peserta didik multikeaksaraan yang diberikan perlakuan

$\mathrm{O} 2=$ tes akhir kelompok peserta didik multikeaksaraan yang diberikan perlakukan (penerapan model)

O4=tes awal kelompok peserta didik multikeaksaraan untuk kelompok kontrol

$\mathrm{O} 3=$ tes akhir kelompok peserta didik multikeaksaraan untuk kelompok kontrol

\section{Sasaran Pengembangan Model}

Objek pengembangan adalah penerapan model pembelajaran multikeaksaraan dengan literasi keuangan pada pendidikan keaksaraan.

\section{Waktu dan Tempat}

a. Waktu pelaksanaan pengembangan selama 3 bulan, yaitu mulai bulan Agustus s.d. bulan November 2018

b. Tempat

1) Kabupaten Bangli

2) Kabupaten Karangasem

\section{Subjek Pengembangan}

Subjek pengembangan adalah pengelola PKBM, tutor, dan peserta didik program keaksaraan yang telah dijadikan sampel dalam pengembangan model.

\section{Variabel Pengembangan}

a. Variabel Bebas

Variabel bebas adalah model pembelajaran literasi keuangan dengan pendekatan PBL.

b. Variabel Terikat

bahan kemampuan respon-den dalam penerapan model. 


\section{Instrumen dan Metode Pengumpulan Data}

a. Istrumen Pengumpul Data

1) Kuesioner

Pedoman wawancara, yaitu sebagai instrumen untuk mengumpulkan data hasil wawancara.

2) Pedoman pengamatan untuk memperoleh data tentang hasil pengamatan.

3) Dokumen hasil penilaian prestasi belajar peserta didik untuk melihat hasil penerapan model pembe-lajaran multikeaksaraan dengan literasi keuangan.

a. Metode Pengumpulan Data

1) Instrumen kuesioner untuk mengumpulkan data tentang keefektifan model.

2) Pedoman pengamatan untuk mengumpulkan data tentang hasil kemampuan membaca peserta didik.

3) Tes kemampuan membaca, menulis, dan berhitung untuk memperoleh hasil penilaian prestasi belajar peserta didik dalam pembelajaran multi-keaksaraan dengan literasi keuangan.

4) Wawancara untuk mengum-pulan data yang ber-hubungan dengan sikap atau pendapat responden terkait dengan model yang sedang dikembangkan.

\section{Analisis Data}

Analisis data disesuaikan dengan teknik dan jenis data yang terkumpul.

Data hasil kuesioner diolah dengan menggunakan persentase dengan cara membagi skor amatan dengan skor maksimal dikalikan dengan 100. Besarnya persentase yang diperoleh dibandingkan dengan kriteria yang ditetapkan.

Data hasil wawancara diolah dengan cara menarasikan dengan menghubungkan keterangan-keterangan atau fakta-fakta sesuai dengan sikap dan pendapat responden.
Data hasil pengamatan diolah dengan menggunakan persentase untuk memperoleh besaran persentase yang mampu dicapai dibandingkan dengan kriteria yang ditetapkan.

Dokumen hasil prestasi belajar tes awal dan tes akhir dianalisis dengan menggunakan uji t dengan taraf kepercayaan 95\%.

Seluruh data terkumpul dicari rata-rata capaiannya dan dikonsultasikan dengan kriteria yang telah ditetapkan sebagai berikut:

$$
\begin{array}{ll}
85 \%-100 \% & =\text { Sangat Layak } \\
70 \%-84 \% & =\text { Layak } \\
55 \%-69 \% & =\text { Cukup } \\
40 \%-54 \% & =\text { Kurang } \\
<40 \% & =\text { Sangat Kurang. }
\end{array}
$$

\section{HASIL PENGEMBANGAN}

\section{Uji Validitas Draf Model}

Untuk menguji validitas draf model, dilakukan uji isi (content validity) dengan cara melalui pendapat para pakar dan praktisi di bidangnya. Pertama-tama uji validitas dilakukan dengan pembahasan isi, struktur, dan sistematika penulisan model melalui forum group discussion yang diselenggarakan oleh BP PAUD dan Dikmas Bali. FGD Draf Model ini dihadiri oleh sebanyak 15 orang yang terdiri atas: (1) pejabat Direktorat Keaksaraan (pusat), (2) pejabat struktural BP PAUD dan Dikmas Bali, (3) tim akademisi, dan (4) praktisi program pendidikan keaksaraan.

Berdsarkan hasil FGD Draf Model, dinyatakan bahwa draf model dapat dilanjutkan dengan sedikit perbaikan. Artinya, secara isi, struktur, dan sistematika, draf model telah memenuhi syarat ketepatan (valid).

Uji validitas berdasarkan isi tidak saja dilakukan melalui FGD draf model, tetapi juga dilakukan melalui uji konseptual model. Uji konseptual dimaksudkan untuk melakukan uji terbatas sebelum dilakukan uji operasional secara meluas. Uji konseptual model dihadiri oleh para pengelola PKBM dan tutor di Kabupaten 
Buleleng. Hasil uji coba konseptual model adalah model dapat digunakan untuk uji operasional dengan catatan ada sedikit perbaikan.

Model dinyatakan valid apabila hasil uji coba sekurang-kurangnya memperoleh skor $>75$. Hasil di atas menunjukkan bahwa keempat perangkat model, yaitu draf model, panduan pembelajaran, panduan penilaian, dan bahan ajar multikeaksaraan literasi keuangan masingmasing mencapai rerata 80,31, 77,21, 75,59, dan 78,07 semuanya $>75$ sehingga dinyatakan valid.

Tabel 1. Hasil Uji Konseptual Model

\begin{tabular}{lcccc}
\hline \multicolumn{1}{c}{ Komponen } & Draf Model & $\begin{array}{c}\text { Panduan } \\
\text { Pembelajaran }\end{array}$ & $\begin{array}{c}\text { Panduan } \\
\text { Penilaian }\end{array}$ & Bahan Ajar \\
\hline Judul & 86,67 & 84,67 & 76,00 & 80,67 \\
Isi & 74,75 & 73,75 & 70,25 & 74,00 \\
Penyajian & 79,00 & 78,00 & 78,50 & 80,00 \\
Bahasa & 80,80 & 72,40 & 77,60 & 77,60 \\
Rerata & 80,31 & 77,21 & 75,59 & 78,07 \\
Keterangan & Valid & Valid & Valid & Valid \\
\hline
\end{tabular}

\section{Uji Efektivitas}

Untuk mengetahui efektivitas model, digunakan rumus Uji t test. Uji t ini digunakan untuk menguji apakah terdapat perbedaan kemampuan keaksaraan secara signifikan antara peserta didik yang menggunakan model dan yang tidak menggunakan model. Sebelum data dianalisis dengan uji t, syarat utama yang dilakukan adalah data harus terdistribusi secara normal sehingga dilakukan uji normalitas data. Diketahui bahwa sampel kelompok operasional sebanyak 50 dan kelompok kontrol sebanyak 25. Dengan kondisi sampel seperti tersebut, pada uji normalitas digunakan Uji Kolmogorov-Smirnov untuk sampel 50 atau lebih dan uji normalitas Shapiro-Wilk untuk sampel kurang dari 50 dengan bantuan SPSS 23 for Windows.

\section{a. Data yang diperoleh}

1) Kelompok Operasional

Tabel 2. Data Hasil Tes Peserta Didik Kelompok Operasional

\begin{tabular}{|c|c|c|c|c|c|c|c|c|c|}
\hline 12 & IWM & 65 & 80 & 70 & 80 & 70 & 70 & 68.33 & 76.67 \\
\hline 13 & NNS & 70 & 80 & 60 & 70 & 70 & 75 & 66.67 & 75.00 \\
\hline 14 & NKS & 60 & 65 & 60 & 75 & 60 & 70 & 60.00 & 70.00 \\
\hline 15 & IKM & 70 & 80 & 70 & 80 & 60 & 70 & 66.67 & 76.67 \\
\hline 16 & NNK & 70 & 80 & 70 & 80 & 80 & 80 & 73.33 & 80.00 \\
\hline 17 & IKS & 65 & 70 & 60 & 70 & 60 & 70 & 61.67 & 70.00 \\
\hline 18 & IKM & 65 & 75 & 70 & 75 & 60 & 70 & 65.00 & 73.33 \\
\hline 19 & NNK & 60 & 70 & 60 & 70 & 60 & 70 & 60.00 & 70.00 \\
\hline 20 & INS & 60 & 70 & 60 & 70 & 60 & 80 & 60.00 & 73.33 \\
\hline 21 & NNL & 70 & 80 & 70 & 70 & 70 & 80 & 70.00 & 76.67 \\
\hline 22 & NWW & 60 & 65 & 60 & 70 & 60 & 70 & 60.00 & 68.33 \\
\hline 23 & NKR & 65 & 80 & 70 & 80 & 70 & 70 & 68.33 & 76.67 \\
\hline 24 & NWR & 60 & 70 & 60 & 70 & 60 & 70 & 60.00 & 70.00 \\
\hline 25 & NKS & 60 & 65 & 60 & 65 & 60 & 70 & 60.00 & 66.67 \\
\hline 26 & NMS & 60 & 70 & 60 & 70 & 60 & 75 & 60.00 & 71.67 \\
\hline 27 & IMB & 60 & 75 & 70 & 80 & 70 & 80 & 66.67 & 78.33 \\
\hline 28 & NWR & 60 & 70 & 70 & 80 & 70 & 70 & 66.67 & 73.33 \\
\hline 29 & NWS & 70 & 80 & 70 & 80 & 70 & 70 & 70.00 & 76.67 \\
\hline 30 & NNP & 70 & 75 & 80 & 90 & 80 & 90 & 76.67 & 85.00 \\
\hline 31 & INT & 70 & 70 & 70 & 70 & 80 & 90 & 73.33 & 76.67 \\
\hline 32 & NNS & 70 & 80 & 70 & 80 & 70 & 80 & 70.00 & 80.00 \\
\hline 33 & NWT & 70 & 80 & 70 & 80 & 70 & 80 & 70.00 & 80.00 \\
\hline 34 & NWG & 60 & 70 & 60 & 65 & 60 & 70 & 60.00 & 68.33 \\
\hline 35 & NNN & 70 & 80 & 70 & 80 & 70 & 80 & 70.00 & 80.00 \\
\hline
\end{tabular}




\begin{tabular}{|r|l|l|l|l|l|l|r|r|r|}
\hline 36 & NKP & 70 & 80 & 70 & 80 & 70 & 70 & 70.00 & 76.67 \\
\hline 37 & NMS & 60 & 65 & 60 & 70 & 60 & 70 & 60.00 & 68.33 \\
\hline 38 & NKT & 70 & 80 & 70 & 80 & 60 & 70 & 66.67 & 76.67 \\
\hline 39 & NNP & 70 & 80 & 70 & 80 & 70 & 80 & 70.00 & 80.00 \\
\hline 40 & NWP & 70 & 80 & 70 & 80 & 70 & 90 & 70.00 & 83.33 \\
\hline 41 & NWT & 70 & 70 & 70 & 80 & 70 & 80 & 70.00 & 76.67 \\
\hline 42 & NWK & 60 & 70 & 60 & 70 & 60 & 70 & 60.00 & 70.00 \\
\hline 43 & NKB & 70 & 80 & 60 & 70 & 60 & 65 & 63.33 & 71.67 \\
\hline 44 & NKM & 70 & 70 & 70 & 80 & 70 & 70 & 70.00 & 73.33 \\
\hline 45 & NMT & 70 & 80 & 70 & 70 & 60 & 70 & 66.67 & 73.33 \\
\hline 46 & NKP & 70 & 80 & 70 & 80 & 60 & 70 & 66.67 & 76.67 \\
\hline 47 & NMS & 60 & 65 & 60 & 70 & 60 & 70 & 60.00 & 68.33 \\
\hline 48 & NMC & 70 & 80 & 70 & 80 & 70 & 80 & 70.00 & 80.00 \\
\hline 49 & NWS & 70 & 80 & 70 & 80 & 70 & 80 & 70.00 & 80.00 \\
\hline 50 & NMG & 3205 & 3640 & 3210 & 3660 & 3230 & 3695 & 3215.00 & 3665.00 \\
\hline & JUMLAH & 64.10 & 72.80 & 64.20 & 73.20 & 64.60 & 73.90 & 64.30 & 73.30 \\
\hline & RERATA & & & & & & & & \\
\hline & & & & & & & & & \\
\hline & & & & & & & & RERATA \\
\hline
\end{tabular}

Dari Tabel 2 di atas, diketahui bahwa rerata kemampuan membaca pretest $=64,10$ dan post-test sebesar 72,80 sehingga terjadi peningkatan sebesar 8,70. Rerata kemampuan menulis pretest 64,20, dan post-test 73,20 sehingga terjadi peningkatan sebesar 9,00. Peningkatan terjadi juga pada rerata kemampuan berhitung pre-test sebesar 64,60 dan post-test sebesar 73,90 sehingga terjadi peningkatan 11,30. Secara keseluruhan menulis, membaca, dan berhitung rerata pre-test $=64,30$ dan post test sebesar 73,30 sehingga terjadi peningkatan kemampuan keaksaraan sebesar $=9,00$.

2) Kelompok Kontrol

Tabel 3. Data Hasil Tes Peserta Didik Kelompok Kontrol

\begin{tabular}{|c|c|c|c|c|c|c|c|c|c|c|}
\hline \multirow[b]{2}{*}{ NO. } & \multirow[b]{2}{*}{ NAMA } & \multicolumn{2}{|c|}{ MEMBACA } & \multicolumn{2}{|c|}{ MENULIS } & \multicolumn{2}{|c|}{ BERHITUNG } & \multicolumn{2}{|c|}{ RERATA } & \multirow{2}{*}{$\begin{array}{l}\text { GAINS } \\
\text { SKOR }\end{array}$} \\
\hline & & $\begin{array}{l}\text { PRE } \\
\text { TEST }\end{array}$ & $\begin{array}{l}\text { POST } \\
\text { TEST }\end{array}$ & $\begin{array}{l}\text { PRE } \\
\text { TEST }\end{array}$ & $\begin{array}{l}\text { POST } \\
\text { TEST }\end{array}$ & $\begin{array}{l}\text { PRE } \\
\text { TEST }\end{array}$ & $\begin{array}{l}\text { POST } \\
\text { TEST }\end{array}$ & $\begin{array}{l}\text { PRE } \\
\text { TEST }\end{array}$ & $\begin{array}{l}\text { POST } \\
\text { TEST }\end{array}$ & \\
\hline 1 & NNN & 50 & 50 & 50 & 55 & 50 & 55 & 50.00 & 53.33 & 3.33 \\
\hline 2 & NMS & 70 & 70 & 70 & 70 & 70 & 70 & 70.00 & 70.00 & 0.00 \\
\hline 3 & IDA & 50 & 50 & 60 & 60 & 60 & 60 & 56.67 & 56.67 & 0.00 \\
\hline 4 & NMT & 60 & 70 & 60 & 50 & 50 & 60 & 56.67 & 60.00 & 3.33 \\
\hline 5 & NMS & 50 & 60 & 50 & 50 & 60 & 50 & 53.33 & 53.33 & 0.00 \\
\hline 6 & NWR & 50 & 50 & 50 & 50 & 50 & 50 & 50.00 & 50.00 & 0.00 \\
\hline 7 & NMR & 40 & 40 & 50 & 40 & 40 & 40 & 43.33 & 40.00 & -3.33 \\
\hline 8 & NKA & 60 & 60 & 60 & 60 & 60 & 70 & 60.00 & 63.33 & 3.33 \\
\hline 9 & NWS & 50 & 50 & 50 & 50 & 60 & 50 & 53.33 & 50.00 & -3.33 \\
\hline 10 & NMK & 60 & 60 & 60 & 70 & 60 & 60 & 60.00 & 63.33 & 3.33 \\
\hline 11 & NWJ & 60 & 60 & 60 & 60 & 60 & 60 & 60.00 & 60.00 & 0.00 \\
\hline 12 & NMK & 50 & 50 & 55 & 50 & 60 & 60 & 55.00 & 53.33 & -1.67 \\
\hline 13 & NMS & 50 & 60 & 60 & 60 & 70 & 70 & 60.00 & 63.33 & 3.33 \\
\hline 14 & NMR & 50 & 60 & 60 & 60 & 70 & 70 & 60.00 & 63.33 & 3.33 \\
\hline 15 & NWA & 70 & 70 & 60 & 70 & 70 & 70 & 66.67 & 70.00 & 3.33 \\
\hline 16 & NMS & 60 & 60 & 60 & 60 & 60 & 70 & 60.00 & 63.33 & 3.33 \\
\hline 17 & NKM & 50 & 50 & 60 & 60 & 60 & 60 & 56.67 & 56.67 & 0.00 \\
\hline 18 & NMD & 50 & 50 & 60 & 60 & 50 & 60 & 53.33 & 56.67 & 3.33 \\
\hline 19 & NKR & 50 & 55 & 50 & 55 & 55 & 55 & 51.67 & 55.00 & 3.33 \\
\hline
\end{tabular}




\begin{tabular}{|c|c|c|c|c|c|c|c|c|c|c|}
\hline \multirow[b]{2}{*}{ NO. } & \multirow[b]{2}{*}{ NAMA } & \multicolumn{2}{|c|}{ MEMBACA } & \multicolumn{2}{|c|}{ MENULIS } & \multicolumn{2}{|c|}{ BERHITUNG } & \multicolumn{2}{|c|}{ RERATA } & \multirow{2}{*}{$\begin{array}{l}\text { GAINS } \\
\text { SKOR }\end{array}$} \\
\hline & & $\begin{array}{c}\text { PRE } \\
\text { TEST }\end{array}$ & $\begin{array}{l}\text { POST } \\
\text { TEST }\end{array}$ & $\begin{array}{l}\text { PRE } \\
\text { TEST }\end{array}$ & $\begin{array}{l}\text { POST } \\
\text { TEST }\end{array}$ & $\begin{array}{l}\text { PRE } \\
\text { TEST }\end{array}$ & $\begin{array}{l}\text { POST } \\
\text { TEST }\end{array}$ & $\begin{array}{l}\text { PRE } \\
\text { TEST }\end{array}$ & $\begin{array}{l}\text { POST } \\
\text { TEST }\end{array}$ & \\
\hline 20 & NKP & 60 & 60 & 60 & 60 & 50 & 60 & 56.67 & 60.00 & 3.33 \\
\hline 21 & NKM & 60 & 60 & 60 & 70 & 60 & 60 & 60.00 & 63.33 & 3.33 \\
\hline 22 & NKR & 60 & 60 & 60 & 60 & 60 & 60 & 60.00 & 60.00 & 0.00 \\
\hline 23 & NWT & 50 & 50 & 60 & 60 & 60 & 60 & 56.67 & 56.67 & 0.00 \\
\hline 24 & NMB & 60 & 60 & 60 & 60 & 50 & 50 & 56.67 & 56.67 & 0.00 \\
\hline 25 & NWB & 50 & 55 & 50 & 55 & 50 & 50 & 50.00 & 53.33 & 3.33 \\
\hline Jumlah & & 1370 & 1420 & 1435 & 1455 & 1445 & 1480 & 1416.67 & 1451.67 & 35.00 \\
\hline Rerata & & 54.8 & 56.8 & 57.4 & 58.2 & 57.8 & 59.2 & 56.67 & 58.07 & 1.4 \\
\hline
\end{tabular}

Dari Tabel 3 di atas, diketahui bahwa rerata kemampuan membaca pre-test peserta didik sebesar 54,80 dan post test sebesar 56,80 sehingga terjadi peningkatan sebesar 2,00. Rerata kemampuan menulis pre-test menulis $=57,40$, dan post test 58,20 sehingga terjadi peningkatan sebesar 0,80 . Rerata kemampuan berhitung pre-test $=57,80$ dan post-test sebesar 59,20 sehingga terjadi kenaikan 1,40. Secara keseluruhan rerata membaca, menulis dan berhitung pre-test $=$ 56,67 dan post-test sebesar 58,07 atau terjadi kenaikan 1,40.

\section{b. Uji Normalitas}

1) Kelompok Operasional

Tabel 4. Hasil Uji Normalitas Data Kelompok Operasional

\begin{tabular}{|c|c|c|c|c|c|c|}
\hline \multicolumn{7}{|c|}{ Tests of Normality } \\
\hline & \multicolumn{3}{|c|}{ Kolmogorov-Smirnova } & \multicolumn{3}{|c|}{ Shapiro-Wilk } \\
\hline & Statistic & $\mathrm{df}$ & Sig. & Statistic & $\mathrm{df}$ & Sig. \\
\hline KELOMPOK & .189 & 50 & .000 & .915 & 50 & .002 \\
\hline OPERASIONAL & & & & & & \\
\hline
\end{tabular}

Kriteria normalitas data $=\mathrm{p}>0.05$

Hasil uji normalitas kelompok operasional diperoleh skor statistik (Kolmogorov-Smirnova) sebesar 0,189 dengan df 50 dan taraf signifikansi 0,05 maka skor statistik lebih besar daripada skor tabel. Kriteria normalitas data skor statistik lebih besar skor tabel. Dengan demikian, data kelompok operasional normal. Dengan pengujian normalitas (Shapiro-Wilk) diperoleh skor statistik sebesar 0,915 dengan df 50 dan harga tabel 0,05, maka skor statistik lebih besar daripada harga tabel. Dengan demikian, data normal.

2) Kelompok Kontrol

Tabel 5. Hasil Uji Normalitas Data Kelompok Kontrol

\begin{tabular}{lccccccr}
\hline \multicolumn{7}{c|}{ Tests of Normality } \\
& $\begin{array}{l}\text { Kolmogorov-Smirnova } \\
\text { Statistic }\end{array}$ & Df & Sig. & Statistic & Df & Sig. \\
\hline $\begin{array}{l}\text { KELOMPOK } \\
\text { KONTROL }\end{array}$ & .326 & 25 & .000 & .763 & 25 & .000 \\
\hline
\end{tabular}

a. Lilliefors Significance Correction

Kriteria normalitas data $=\mathrm{p}>0.05$. 
Hasil uji normalitas kelompok kontrol diperoleh skor statistik (KolmogorovSmirnova) sebesar 0,326 dengan df 25 dan taraf signifikansi 0,05 maka skor statistik lebih besar daripada skor tabel. Dengan demikian, data kelompok operasional normal. Dengan pengujian normalitas (Shapiro-Wilk) diperoleh skor statistik sebesar 0,763 dengan $\mathrm{df}$ 25 dan harga tabel 0,05, maka skor statistik lebih besar daripada harga tabel. Dengan demikian, data normal.

\section{c. Uji Homogenitas}

Setelah data dinyatakan normal, langkah selanjutnya adalah menguji homogenitas varian. Uji homogenitas varian ini untuk menentukan teknik statistik apa yang akan digunakan.

$$
\begin{aligned}
& \mathrm{Ho}=0 \\
& \mathrm{Ha} \neq 0
\end{aligned}
$$

Kriteria varian homogen apabila $\mathrm{F}$ hitung $=0$.

Rumus yang digunakan

$\mathrm{F}=$ Varian tertinggi : varian terendah

Berdasarkan hasil perhitungan dengan bantuan SPSS 23 for Windows diperoleh data sebagai berikut.

$$
\begin{aligned}
& S 1=2,28935 \\
& S 2=2,23825 \\
& S 1^{2}=5,24112
\end{aligned}
$$

$$
\begin{aligned}
\mathrm{S}^{2} & =5,0098 \\
\mathrm{~F} & =5,24112: 5,0098 \\
& =1,046
\end{aligned}
$$

Harga $F$ tabel dengan pembilang 50 dan penyebut $25=1,84$.

Kesimpulan F hitung lebih kecil daripada F tabel, maka data homogen.

\section{d. Rumus Uji t}

$\mathrm{t}=$ koefisien nilai $\mathrm{t}$ (perbedaan)

$\mathrm{x} 1$ = rerata gains skor kelompok eksperimen

x2 = rerata gains skor kelompok kontrol

s1 = standar deviasi kelompok eksperimen

s2 = standar deviasi kelompok kontrol

$\mathrm{n} 1$ = jumlah siswa kelompok eksperimen

$\mathrm{n} 2$ = jumlah siswa kelompok kontrol

1) Hipotesis

$\mathrm{Ha}=$ menerima $\mathrm{Ha}$ apabila hasil $\mathrm{t}$

\begin{tabular}{|c|c|c|c|c|}
\hline \multicolumn{5}{|c|}{ One-Sample Statistics } \\
\hline & $\mathrm{N}$ & Mean & Std. Deviation & Std. Error Mean \\
\hline \multirow[t]{3}{*}{ KELOMPOK OPERASIONAL } & 50 & 8.9996 & 2.28395 & .32300 \\
\hline & \multicolumn{2}{|c|}{ One-Sample Statistics } & & \\
\hline & $\mathrm{N}$ & Mean & Std. Deviation & Std. Error Mean \\
\hline KELOMPOK KONTROL & 25 & 1.3324 & 3.60052 & .72010 \\
\hline
\end{tabular}
hitung lebih kecil dari t tabel.

$\mathrm{H} 0=$ menolak Ho apabila hasil $\mathrm{t}$ hitung lebih besar dari t tabel.

2) Hasil Analisis Data

Berdasarkan tabel di bawah dengan bantuan SPSS, maka dapat diketahui hasil analisis data sebagai berikut.

$\begin{array}{ll}\text { X1 (kelompok operasional }) & =8,9996 \\ \text { X2 (kelompok Kontrol }) & =1.3324 \\ \text { S X1 } & =2,28395 \\ \text { S X2 } & =3,60052\end{array}$

$$
\begin{aligned}
& t=\frac{8,9996-1,3324}{\sqrt{\frac{2,28395}{50}+\frac{3,60052}{25}}} \\
& t=\frac{7,6672}{0,4355454052} \\
& \mathrm{t}=17,60
\end{aligned}
$$


Berdasarkan hasil analisis, diperoleh t hitung sebesar 17,60 dengan $\mathrm{db} 49$ dan taraf kepercayaan $95 \%$, diperoleh harga tabel sebesar $=2,060$. Dengan demikian, thitung lebih besar daripada $\mathrm{t}$ tabel.

Hipotesis nol ditolak, yang menyatakan tidak ada perbedaan antara kemampuan keaksaraan peserta didik yang menerapkan model dengan kemampuan keaksaraan peserta didik yang tidak menerapkan model.

Menerima hipotesis alternatif yang menyatakan bahwa ada perbedaan antara kemampuan keaksaraan peserta didik yang menerapkan model dengan kemampuan keaksaraan peserta didik yang tidak menerapkan model.

\section{Uji Penerapan Draf Model}

a. Data Penerapan Bahan Ajar Tabel 6. Data Hasil Uji Coba Bahan Ajar

\begin{tabular}{|c|l|c|c|c|}
\hline No. & \multicolumn{1}{|c|}{ Aspek } & $\begin{array}{c}\text { Karang- } \\
\text { asem }\end{array}$ & Bangli & Rerata \\
\hline 1 & Judul naskah & 73.33 & 81.33 & 77.33 \\
\hline 2 & Isi materi & 71.50 & 74.00 & 72.75 \\
\hline 3 & $\begin{array}{l}\text { Penyajian } \\
\text { materi }\end{array}$ & 77.00 & 74.00 & 75.50 \\
\hline 4 & $\begin{array}{l}\text { Bahasa dan } \\
\text { keterangan }\end{array}$ & 80.80 & 75.20 & 78.00 \\
\hline Jumlah persentase & 302.63 & 304.53 & 303.58 \\
\hline
\end{tabular}

Hasil uji coba bahan ajar terhadap kelompok operasional di PKBM Dharma Sedana Shanti memperoleh nilai sebesar 75,66 dan di PKBM Niti Sastra Mandala memperoleh skor penilaian sebesar 76,13 atau secara keseluruhan rerata penilaian terhadap bahan ajar yang digunakan sebesar 75,90. Berdasarkan kriteria yang telah ditetapkan, perolehan skor penilaian sebesar 75,90 termasuk dalam kategori baik atau dapat diterapkan. b. Data Penerapan Model

Tabel 7. Data Hasil Uji Coba Model

\begin{tabular}{|c|c|c|c|c|c|}
\hline \multirow{2}{*}{ No. } & \multirow{2}{*}{ Aspek } & Pendidik & $\begin{array}{l}\text { Peserta } \\
\text { Didik }\end{array}$ & Pendidik & $\begin{array}{c}\text { Peserta } \\
\text { Didik }\end{array}$ \\
\hline & & $\begin{array}{c}\mathrm{Kr} . \\
\text { Asem }\end{array}$ & $\begin{array}{c}\mathrm{Kr} . \\
\text { Asem }\end{array}$ & Bangli & Bangli \\
\hline 1 & $\begin{array}{l}\text { Fase indentifikasi } \\
\text { masalah }\end{array}$ & 83.33 & 67.00 & 80.67 & 67.40 \\
\hline 2 & Fase orientasi & 84.00 & 66.40 & 71.33 & 80.27 \\
\hline 3 & $\begin{array}{l}\text { Fase mengorgani- } \\
\text { sasikan peserta } \\
\text { didik }\end{array}$ & 69.60 & 73.00 & 64.40 & 65.20 \\
\hline 4 & $\begin{array}{l}\text { Fase } \\
\text { membimbing } \\
\text { individu atau } \\
\text { kelompok }\end{array}$ & 71.00 & 73.07 & 87.00 & 85.07 \\
\hline 5 & $\begin{array}{l}\text { Fase mengem- } \\
\text { bangkan dan } \\
\text { menyajikan hasil } \\
\text { karya }\end{array}$ & 74.00 & 90.80 & 85.00 & 94.40 \\
\hline 6 & $\begin{array}{l}\text { Fase meng- } \\
\text { analisis dan } \\
\text { mengevaluasi } \\
\text { proses } \\
\text { pemecahan } \\
\text { masalah }\end{array}$ & 74.00 & 80.27 & 79.33 & 70.13 \\
\hline jumle & h persentase & 455.93 & 450.53 & 467.73 & 462.47 \\
\hline rata- & ata persentase & 75.99 & 75.09 & 77.96 & 77.08 \\
\hline
\end{tabular}

Hasil uji coba penerapan model terhadap pendidik kelompok operasional di PKBM Dharma Sedana Shanti memperoleh penilaian sebesar 75,99 dan peserta didik sebesar 75,09. Sementara itu, di PKBM Niti Sastra Mandala diperoleh skor penilaian pendidik sebesar 77,96 dan pendidik sebesar 77,08.

Untuk persentase secara keseluruhan di Karangasem dan Bangli, penilaian pendidik terhadap penerapan model sebesar 76,98 dan penilaian peserta didik terhadap penerapan model sebesar 76,09. Sesuai dengan kriteria yang ditetapkan, skor tersebut termasuk dalam kategori baik atau dapat diterapkan.

\section{c. Hasil Pengamatan}

Hasil pengamatan terhadap proses belajar mengajar adalah sebagai berikut.

1) Peserta Didik

a) Peserta didik lebih antusias dalam mengikuti proses belajar mengajar, 
dibuktikan dengan meningkatnya kehadiran dalam pembelajaran.

b) Meningkatkan keterlibatan peserta didik dalam kegiatan pembelajaran, seperti kerja kelompok dan penyelesaian tugas-tugas yang diberikan.

c) Peserta didik bersemangat dalam mengerjakan tugas, baik perorangan maupun berkelompok.

d) Peserta didik aktif dalam mengikuti proses pembelajaran.

2) Pendidik

a) Lebih fokus dalam materi pembelajaran sesuai dengan fase yang telah ditetapkan.

b) Pembelajaran berjalan sesuai dengan kurikulum yang ada.

c) Proses pembelajaran lebih interaktif.

d) Pemanfaatan bahan ajar sangat mendukung dalam proses pembelajaran.

e) Penilaian dilaksanakan sesuai dengan pedoman yang ditetapkan.

\section{d. Hasil Wawancara}

Hasil wawancara dengan pendidik dan peserta didik antara lain sebagai berikut.

1) Tokoh masyarakat, dalam hal ini kepala dusun, sangat mendukung adanya program multikeaksaraan sehingga warga masyarakat yang sudah melek aksara tidak kembali buta huruf lagi.

2) Mendukung penerapan model pembelajaran multikeaksara-an dengan pendekatan problem based learning.

3) Mendorong keterlibatan warga belajar aktif dalam kegiatan pembelajaran.

4) Berharap ada program pendampingan dari program multikeak- saraan, misalnya dengan usaha tertentu sehingga lebih memberi semangat bagi masyarakat.

5) Program-program yang bersentuhan dengan masyarakat itu hendaknya lebih diarahkan ke keterampilan sesuai dengan potensi lokal agar masyarakat lebih bergairah dalam belajar dan sekaligus dapat meningkatkan penghasilan.

\section{PENUTUP}

\section{Simpulan}

Berdasarkan hasil analisis sebagaimana telah diuraikan, dapat disimpulkan hal-hal sebagai berikut.

a. Pada model pembelajaran literasi keuangan dengan pendekatan problem based learning, dalam uji coba model diperoleh skor 80,31 atau dalam kriteria baik. Panduan pembelajaran literasi keuangan dengan pendekatan problem based learning dalam uji coba model diperoleh skor 77,21 atau dalam kriteria baik, Panduan penilaian diperoleh skor 75,59 atau dalam kriteria baik dan bahan ajar diperoleh skor 78,07 atau dalam kriteria baik. Secara keseluruhan, untuk hasil uji coba model diperoleh rerata sebesar 77,80 atau dalam kriteria baik. Dengan demikian, model tersebut termasuk dalam kriteria baik atau valid.

b. Untuk hasil uji efektivitas model antara kelompok operasional dengan kelompok kontrol, diperoleh skor $\mathrm{t}$ hitung $=17,60$. Adapun t tabel dengan db 49 dan taraf kepercayaan 95\% sebesar 2,060, maka t hitung > daripada $t$ tabel. Dengan demikian, Hipotesis Nol yang menyatakan tidak ada perbedaan kemampuan keaksaraan antara peserta didik yang menggunakan model dengan peserta didik yang tidak menggunakan ditolak. Hipotesis Alternatif yang menyatakan ada perbedaan kemampuan keaksaraan peserta didik yang menggunakan model dengan peserta didik 
yang tidak menggunakan model diterima. Dengan demikian, model tersebut efektif dalam meningkatkan hasil belajar program keaksaraan.

c. Hasil uji coba penerapan bahan ajar diperoleh skor sebesar 75,90 atau dalam kriteria baik. Sementara itu, pada uji coba penerapan untuk pendidik diperoleh skor sebesar 76,98 atau dalam kriteria baik. Demikian pula, hasil uji coba terhadap peserta didik diperoleh skor sebesar 76,09 atau dalam kriteria baik. Secara keseluruhan, hasil uji coba penerapan terhadap model diperoleh rerata skor 76,32 atau dalam kriteria baik sehingga model dapat diterapkan.

\section{Saran-Saran}

Sehubungan dengan kesimpulan di atas, disarankan hal-hal sebagai berikut.

a. Dalam pelaksanaan model pembelajaran literasi keuangan dengan pendekatan problem based learning ini, syarat mutlak yang diperlukan adalah bahwa peserta didik harus sudah mampu atau lulus keaksaraan dasar. Oleh karena itu, dalam penentuan peserta didik agar hal tersebut mendapatkan perhatian.

b. Pembelajaran multikeaksaraan dengan pendekatan problem based learning memerlukan tahapan sesuai dengan sintaks yang ada. Oleh karena itu, disarankan kepada tutor untuk dapat menerapkan fase-fase yang telah ditetapkan agar pelaksanaan pembelajaran model ini dapat berjalan sesuai dengan rencana.

c. Dalam pembelajaran literasi keuangan dengan pendekatan problem basedlearning, sangat diperlukan perangkat pembelajaran seperti bahan ajar pendukung, panduan pembelajaran, panduan penilaian. Oleh karena itu, suksesnya pembelajaran dengan model ini sangat bergantung pada kelengkapan perangkat seperti dimaksud. d. Dalam pembelajaran keaksaraan pada umumnya masyarakat memerlukan program pendampingan, seperti program kecakapan berusaha. Oleh karena itu, masyarakat menginginkan ada kombinasi antara program multikeaksaraan dengan program berusaha sehingga masyarakat akan merasa bergairah dalam belajar.

\section{DAFTAR PUSTAKA}

Arends, L. Richard. (2008). Learning to Teach. Yogyakarta: Pustaka Pelajar.

Departemen Pendidikan dan Kebudayaan. (2009). Peraturan Menteri Pendidikan Nasional Nomor 63 Tahun 2009 tentang Sistem Penjaminan Mutu Pendidikan.

--, (2012). Peraturan Pemerintah Nomor 19 Tahun 2005 tentang Standar Nasional Pendidikan, sebagaimana telah Diubah Dengan Peraturan Pemerintah Nomor 32 Tahun 2012 tentang Perubahan Peraturan Pemerintah Nomor 19 Tahun 2005 tentang Standar Nasional Pendidikan.

Ditentis. (1998). Metode Belajar Orang Dewasa. Modul. Jakarta.

Kuntoro, Sodiq A. (1999). "Andragogi: Teori Pembelajaran Orang Dewasa". Makalah. Yogyakarta.

M. Taufiq Amir. (2009). Inovasi Pendidikan Melalui Problem Based Learning. Jakarta: Media Group.

Aris, Shoimin. (2014). Model Pembelajaran Inovatif dalam Kurikulum 2013. Yogyakarta : Ar-Ruzz Media.

Soedomo. (1989). Pendidikan Luar Sekolah ke Arah Pengembangan Sistem Belajar Masyarakat. Jakarta: Ditjen Dikti, Depdikbud.

Srinivasan, Lyra (1977). Perspectives on Nonformal Adult Learning. New York: World Educational.

Sri Anitah. (2011). Media Pembelajaran. Surakarta: LPP UNS dan UNS Press.

Sugiyono, (2016). Metode Penelitian dan Pengembangan. Bandung: Alfa Beta.

Syamsu, M. dkk. (1994). Teori Belajar Orang Dewasa. Jakarta: Depdikbud.

Tilaar, H.A.R., (2006). Standarisasi Pendidikan Nasional Suatu Tinjauan Kritis. Jakarta: Rineka Cipta.

Trianto. (2007). Model-model Pembe-lajaran Inovatif Berorientasi Konstruktivistik. Jakarta: Prestasi Pustaka.

Undang-Undang RI Nomor 20 Tahun 2003 tentang Sistem Pendidikan Nasional.

Wina Sanjaya. (2008). Strategi Pembelajaran Berorientasi Standar Proses Pendidikan. Jakarta: Prenada Media Group. 